\title{
MERDEKA BELAJAR DALAM KENDALI TATA TERTIB SEKOLAH GUNA MEMBENTUK KARAKTER SISWA KELAS X RPL 1 MELALUI LAYANAN KONSELING KELOMPOK PADA SEMESTER GANJIL DI SMK NEGERI 6 JEMBER TAHUN PELAJARAN 2019/2020
}

\author{
Isnayah
}

SMK Negeri 6 Jember

iznayahari@gmail.com

\begin{abstract}
Abstrak
Kondisi pendidikan kita saat ini dapat digambarkan sebagai kelas tanpa guru. Anak-anak belajar ketika ada guru. Tapi langsung riuh ramai ketika guru meninggalkan kelas, Tujuan penelitian yaitu untuk mengetahui apakah konseling kelompoh dapat menumbuhkan kemerdekaan belajar Siswa dalam kendali tata tertib Sekolah guna membentuk karakter Siswa, Subyek penelitian berjumlah 7 siswa Kelas X RPL 1 dengan metode pengumpulan datanya menggunakan angket, dokumentasi, dan observasi selanjutnya akan dianalisis menggunakan tindakan deskriptif kuantitatif dan analisis observasi, Hasil penelitian pelaksanaan layanan konseling kelompok dapat menumbuhkan kemerdekaan belajar Siswa dalam kendali tata tertib Sekolah serta dapat membentuk karakter Siswa.
\end{abstract}

Kata Kunci: Merdeka Belajar, Tata Tertib Sekolah, Karakter Siswa, Konseling Kelompok)

\begin{abstract}
The current condition of our education can be described as a class without teachers. Children learn when there is a teacher. But immediately boisterous when the teacher leaves the classroom, the research objective is to find out whether group counseling can foster student independence in the control of the school order to form the character of the Student, the research subjects are 7 students of Class X RPL 1 with the data collection method using questionnaires, documentation, and further observations will be analyzed using quantitative descriptive measures and analysis of observations, the results of research into the implementation of group counseling services can foster the independence of student learning in the control of the school discipline and can shape student character.
\end{abstract}

Keywords: Freedom of Learning, School Rules, Student Character, Group Counseling).

\section{PENDAHULUAN}

Kondisi pendidikan kita saat ini dapat digambarkan sebagai kelas tanpa guru. Anak-anak belajar ketika ada guru. Tapi langsung riuh ramai ketika guru meninggalkan kelas. Bukan salah anak-anak yang memang tidak dibiasakan merencanakan sendiri proses belajarnya.

Belajar yang semula aktivitas alami anak dirampas menjadi agenda orang dewasa yang dipaksakan pada anak. Pendidik mendikte dimana dan kapan waktu belajar, tanpa peduli apapun yang sedang dialami anak. Pendidik mendikte tujuan dan materi yang harus dipelajari anak, meski tidak relevan dalam kehidupan anak.

Bila ada anak yang membandel, orang dewasa berusaha mengendalikannya dengan ganjaran dan hukuman. Diiming-iming ganjaran bila anak kembali belajar. Diberi ancaman hukuman mulai hukuman fisik hingga tidak lulus ujian atau tidak naik kelas. Tidak heran bila ujian masih dijadikan monster untuk menakut-nakuti anak agar belajar.

Ajaran Ki Hajar Dewantara. Beliau menekankan berulang kali tentang kemerdekaan belajar. “...kemerdekaan hendaknya dikenakan terhadap caranya anak-anak berpikir, yaitu jangan selalu "dipelopori", atau disuruh mengakui buah pikiran orang lain, akan tetap biasakanlah anak-anak mencari sendiri segala pengetahuan dengan menggunakan pikirannya sendiri..." Ki Hadjar Dewantara (buku Peringatan Taman-Siswa 30 Tahun, 1922-1952). Anak pada dasarnya mampu berpikir untuk "menemukan" suatu pengetahuan.

Apa arti kemerdekaan dalam pernyataan beliau tersebut? Dalam sebuah tulisan di buku Pendidikan, beliau menyatakan "Dalam pendidikan harus senantiasa diingat bahwa kemerdekaan itu bersifat tiga macam: berdiri sendiri, tidak tergantung pada orang lain, dan dapat mengatur diri sendiri".

Berdiri sendiri berarti kemerdekaan belajar mengakui anak sebagai pemilik belajar. Anak mempunyai kewenangan dan inisiatif untuk belajar. Anak belajar tidak harus berhimpun dalam suatu kesatuan seperti kelas atau rombongan belajar.

Tidak tergantung pada orang lain berarti anak belajar tanpa tergantung pada hadir atau tidak hadirnya orang dewasa. Dengan atau tanpa kehadiran guru di kelas atau dengan atau tanpa kehadiran orang tua di rumah, anakanak tetap belajar. 
Melihat kasus tersebut, peneliti selaku guru bimbingan konseling mengupayakan beberapa langkah berkaitan dengan mengurangi kebiasaan belajar siswa jika ada guru saja, dan siswa yang bandel sering melanggar tata tertib dengan menggunakan layanan konseling kelompok. Merdeka belajar adalah ketekunannya dalam perjalanan menuju tujuan yang bermakna bagi diri sendiri. Meichati (1980: 151) tata tertib menurut Meichati dimaknai sebagai sebuah peraturan yang bersifat mengikat seseorang atau kelompok, bertujuan untuk menciptakan keamanan, ketentraman, orang tersebut atau sekelompok orang tersebut, dalam pendapat ini disebutkan pula tujuan dari tata tertib itu sendiri yaitu untuk menjaga keamanan di dalam masyarakat. Karakter merupakan ciri khas individu yang ditunjukkan melalui cara bersikap, berperilaku, dan bertindak untuk hidup dan bekerjasama, baik dalam lingkungan sekolah, keluarga, maupun masyarakat. Anak memiliki karakter baik akan menjadi orang dewasa yang mampu membuat keputusan dengan baik dan tepat serta siap mempertanggungjawabkan setiap keputusan diambil. Konseling kelompok merupakan salah satu pendekatan yang direkomendasikan untuk mendorong perkembangan identitas

(Archer, 1994 ; Maria, dalam Archer, 1994). Penggunaan Konseling kelompok dalam konteks ini juga dipandang tepat karena sasaran intervensi dalam penelitian ini adalah sekelompok individu yang berada pada periode perkembangan remaja, minat-minat sosial menjadi semakin berkembang dan ini dapat dilihat khususnya pada ketertarikan yang kuat pada remaja terhadap kelompok teman sebaya (Steinberg, 1993; 2002)

Rumusan penelitian ini yakni Apakah Konseling kelompok dapat mewujudkan kemerdekaan belajar Siswa dalam kendali tata tertib Sekolah guna membentuk karakter Siswa di Kelas X RPL 1? Sedangkan tujuan dalam penelitian ini: Bagi Guru (1) Mampu menumbuhkan kemerdekaan belajar Siswa dalam kendali tata tertib Sekolah guna membentuk karakter Siswa, (2) Mampu mengaplikasikan Konseling kelompok. Bagi Siswa, (1) Mampu membentuk karakter Siswa sehingga bisa merdeka belajar dalam kendali tata tertib Sekolah, (2) Mampu melatih diri, untuk menumbuhkan karakter Siswa, (3) Mampu berperilaku positif, sehingga mewujudkan Siswa dapat merdeka belajar (4) Mampu membentuk Siswa untuk mematuhi dan melaksanakan Tata tertib Sekolah.

\section{METODE}

Penelitian ini menggunakan metode penelitian tindakan kelas (PTK). Peneliti lebih menyebutnya dengan PTBK sebab penelitiannya dalam ranah bimbingan konseling. Prosedur penelitian tindakan kelas menurut Suharsimi Arikunto (2009) model bagan penelitian tindakan secara garis besar terdapat 4 tahapan yang lazim dilalui yaitu (1) Perencanaan, (2) Pelaksanaan, (3) Pengamatan, dan (4) Refleksi. Karena itu untuk menumbuhkan merdeka belajar dalam kendali tata tertib sekolah guna membentuk karakter Siswa Peneliti melakukan tindakan dengan dua siklus

PTBK ini dilaksanakan dengan 2 siklus dengan subjek penelitian yaitu 7 siswa kelas X RPL 1 metode pengumpulan datanya menggunakan angket, dokumentasi, dan observasi selanjutnya akan dianalisis menggunakan tindakan deskriptif kuantitatif dan analisis observasi.

Peneliti menganalisis data penelitian tindakan bimbingan dan konseling melalui cara membandingkan antara data yang diperoleh pada saat kondisi awal sebelum diadakan tindakan, dibandingkan dengan data yang diperoleh setelah melalui tindakan pada siklus pertama dengan melalui tindakan pada siklus kedua, disebut juga dengan menggunakan tindakan deskriptif kuantitatif dan analisis observasi.

\section{HASIL DAN PEMBAHASAN}

Berdasarkan hasil Konseling kelompok Pada Siklus I ini diperoleh data bahwa dari 7 Siswa anggota Konseling kelompok hampir semuanya merasa tertekan dengan adanya tata tertib Sekolah sehingga mereka menunjukkan sikap yang kurang baik dan tingkah laku yang bermacammacam tidak mencerminkan karakter yang baik sebagai Siswa, mereka tidak atau belum memdapatkan solusi yang tepat untuk menyelesaikan masalah yang dialami masingmasing.

Pada siklus I ini di peroleh data dari anggota konseling kelompok sejumlah 7 orang Siswa sebagai berikut untuk Siswa yang memberikan jawaban pada angket yang sudah di bagikan adalah yang memberi jawaban sangat setuju tidak ada satupun yang memberikan jawaban tersebut atau 0 poin, yang memberikan jawaban setuju sejumlah 13 poin dengan prosentase $18,57 \%$, yang memberikan jawaban tidak setuju sejumlah 35 poin dengan prosentase $50 \%$, yang memberikan jawaban sangat tidak setuju sejumlah 22 poin dengan prosentase $31,43 \%$ dengan demikian menunjukkan kurang merasakan manfaat konseling kelompok untuk itu masih di perlukan tindakan berikutnya yaitu di laksanakan konseling kelompok berikutnya dengan membahas bersama masing-masing permasalahan yang di hadapi anggota kelompok pada siklus ke II

Pada Siklus II ini diperoleh data bahwa dari 7 Siswa anggota konseling kelompok hampir semuanya sudah merasa nyaman dan dapat menerima tata tertib dan mereka menyadari bahwa tata tertib untuk kebaikan mereka sendiri sehingga terbentuk karakter yang baik, dengan adanya tata tertib Sekolah dapat melatih diri mereka untuk disiplin, menghargai waktu, tahu tujuan belajar di sekolah, merasa nyaman dengan kondisi 
lingkungan yang kondusif dapat melaksanakan belajar dengan menyenangkan melatih untuk mandiri dalam menyelesaikan permasalahan yang di hadapi.

Pada siklus II ini di peroleh data dari anggota konseling kelompok sejumlah 7 orang Siswa sebagai berikut untuk Siswa yang memberikan jawaban pada angket yang sudah di bagikan adalah yang memberi jawaban sangat setuju 31 poin dengan prosentase 44,29\%, yang memberikan jawaban setuju sejumlah 34 poin dengan prosentase $48.57 \%$, yang memberikan jawaban tidak setuju sejumlah 4 poin dengan prosentase $5.71 \%$, yang menjawab sangat tidak setuju sejumlah 1 poin dengan prosentase $1.43 \%$, dengan demikian mereka menunjukkan manfaat di laksanakannya konseling kelompok untuk keperntingan mereka sendiri yaitu untuk menyelesaikan kesulitankesulitan yang mereka alami saat ini.

Dari paparan data pada tabel 4.6 dapat di lihat bahwa ada kenaikan semangat Siswa dalam melaksanakan konseling kelompok, dari 10 macam pertanyaan pada siklus I yang menjawab sangat setuju tidak ada atau 0, yang menjawab setuju dengan jumlah 13 poin, yang menjawab tidak setuju 35 poin, sedang sangat tidak setuju jumlah 22 poin itu berarti konseling kelompok belum di rasakan manfaatnya oleh anggota kelompok mereka masih kurang bisa mempercayai kegiatan konseling kelompok tetapi setelah di laksanakan konseling kelompok pada siklus II mengalami peningkatan yang menjawab sangat setuju 31 poin, menjawab setuju 21 poin, yang menjawab tidak setuju masih 4 poin dengan adanya selisih 31 poin, 21 poin ini menunjukkan peningkatan kepercayaan Siswa terhadap proses konseling kelompok, selisih -31 poin ini menunjukkan penurunan jawaban dari anggota konseling kelompok, selisih -21 poin ini juga menunjukkan penurunan jawaban Siswa anggota konseling kelompok itu berarti mengalami penurunan dratis dengan demikian Siswa sudah merasakan manfaat konseling kelompok, berikutnya yang menjawab sangat tidak setuju 1 poin saja itu berarti dari 7 orang Siswa anggota Konseling kelompok hanya satu Siswa yang masih merasakan kurang memberikan manfaat untuk dirinya dan perlu di lakukan tindakan lebih lanjut.

\section{Gambar dan Tabel}

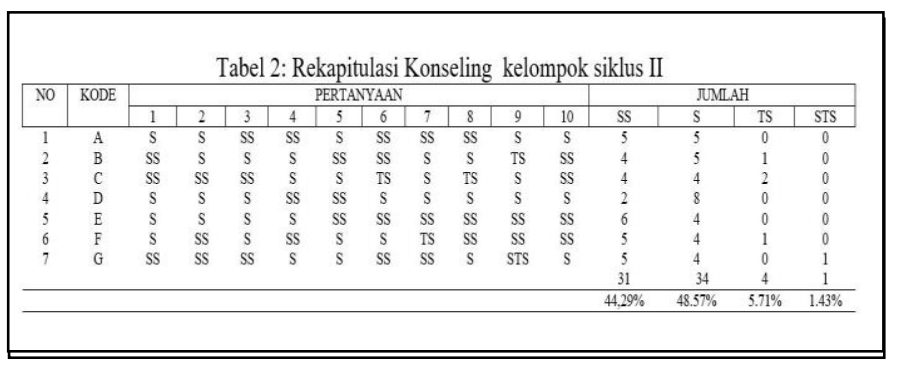

Gambar 1. Contoh keterangan gambar

\section{PENUTUP}

\section{Simpulan}

Berdasarkan uraian dan perolehan data diatas, maka

\begin{tabular}{|l|c|c|c|c|c|c|}
\hline \multirow{2}{*}{ Tabel 3:Perbandingan hasil konseling kelompok sebelum dan sesudah tindakan } \\
\hline \multirow{2}{*}{ PERNYATAAN SISWA } & \multicolumn{2}{|c|}{ SIKLUS I } & \multicolumn{2}{c|}{ SIKLUS II } & $\begin{array}{c}\text { SELISIH } \\
\text { SIKLUS }\end{array}$ & $\begin{array}{c}\text { TINGKAT } \\
\text { KETERCAPAIAN } \\
\text { KONSELNG }\end{array}$ \\
\cline { 2 - 6 } & JUMLAH & $\%$ & JUMLAH & $\%$ & & \\
\hline Sangat Setuju & 0 & $0 \%$ & 31 & $44,29 \%$ & 31 & $44,29 \%$ \\
Setuju & 13 & $18.57 \%$ & 34 & $48,57 \%$ & 21 & $30 \%$ \\
Tidak Setuju & 35 & $50 \%$ & 4 & $5.71 \%$ & -31 & $44,29 \%$ \\
Sangat Tidak Setuju & 22 & $31,43 \%$ & 1 & $1,43 \%$ & -21 & $30 \%$ \\
\hline
\end{tabular}

Peneliti dapat menarik kesimpulan sebagai berikut:

Untuk menumbuhkan merdeka belajar Siswa, dapat dilakukan dengan melaksanakan dan mematuhi tata tertib sekolah dengan kesadaran diri yang tinggi sehingga terwujut karakter yang baik untuk Siswa. (2) Layanan paling tepat untuk menumbuhkan karakter Siswa adalah dengan memberikan layanan konseling kelompok. (3) Layanan konseling kelompok dapat digunakan untuk membantu Siswa yang mengalami kesulitan dalam memecahkan masalahnya sendiri atau dapat mencari jalan keluar secara bersama-sama sehingga mereka secara sadar tanpa merasa terpaksa untuk lebih bersemangat dalam melaksanakan tata tertib Sekolah yang akan membentuk karakter Siswa sehingga akan terwujut Siswa merdeka belajar. (4)Manfaat dari konseling kelompok untuk menumbuhkan karakter Siswa adalah: (1) Memupuk rasa persaudaraan, senasib, seperjuangan sesama Siswa. (2) Memupuk rasa disiplin, pandai menghargai waktu.(3) Dapat berpikir obyektif, sportif, cepat, tepat dalam segala hal. (4) Membuat sikap positif terhadap keadaan diri maupun lingkungannya. (4) Dapat melaksanakan kegiatan yang nyata dan langsung untuk membuahkan hasil yang sesuai dengan cita-cita.

\section{Saran}

Dapat ditingkatkan lagi dalam membentuk karakter siswa dengan merdeka belajar melalui tata tertib sekolah. Dengan layanan konseling kelompok dapat membuat siswa mampu dalam mengembangkan kemampuan dan juga dapat membiasakan kebiasaan belajar dengan adanya merdeka belajar. 


\section{DAFTAR PUSTAKA}

Arikunto, Suharsimi. 2009. Peneitian Tindakan Kelas. Jakarta: PT Bumi Aksara Depdiknas. 2005. Panduan

Pengembangan Diri. Jakarta: Depdiknas

Agus Wibowo. 2013. Manajemen Pendidikan Karakter di Sekolah: Konsep dan Praktik Implementasi. Yogyakarta: Pustaka Pelajar.

Ahmadi, Abu.1982. Bimbingan dan penyuluhan Disekolah, (Semarang: CV.Toha Putra)

Archer, Sally L. (1994). Interventions for Adolescent Identity Development. London: SAGE Publications

Arikunto, Suharsimi. 2002. Prosedur Penelitian Suatu Pendekatan Praktek(Yogyakarta: Rineka Cipta).

Azwar, Saifuddin. 1998. Metode Penelitian (Yogyakarta: Pustaka Belajar).

Kemmis, S. \& Mc. Taggart, R. 1988. The Action Research Planner. Victoria: Deakin University Press.

Buku Peringatan Taman-Siswa 30 Tahun, 1922-1952

Dwi Hastuti Mardiyanto, 2002. Pendidikan Moral pada Anak Didik. Jakarta: Kencana

Depdikbud 2005. Pedoman Pelaksanaan Pelayanan Bimbingan Konseling Jakarta. Balai Pustaka

Gazda, G.M. (1984). Group Counseling A Developmental Approach. Boston: Allyn and Bacon.

Gazda, George M. 1989. Group Counseling: a Developmental Approach. Jakarta: Galia Indonesia

Gladding, Samuel T.(1995). Grup York: A Counseling Specialty. $2^{\text {nd }}$ ed. New Jersey: Merrill, an Imprint Of Prentice Hall

Hadi, sutrisno. 2000. Metodologi Research (Yogyakarta: PT. Andi Jilid 3).

Koesoma. 2007. Pendidikan Karakter pada Sekolah. Jakarta: Kencana

Lickona, Thomas. (1991). Educating for Character: How Our School Can Teach Respect and Responsibility. New York, Toronto, London, Sydney, Aucland: Bantam books.

Meichati, siti, Pengantar Ilmu Pendidikan, Yogyakarta: FIP.IKIP, 1980

Moleong, Lexy. (2002). Metodologi Penelitian Kualitatif. Bandung: PT. remaja Rosdakarya.

M. Fadlillah, Lilif Mualifatu Khorida. 2013. Pendidikan Karakter Anak Usia Dini: Konsep \& Aplikasinya dalam PAUD. Yogyakarta: Ar-Ruz Media.

Prayoga, Ogas. Pengaruh Digital Divide Terhadap ICT Literacy Guru di SMKN Kota Bandar Lampung. Fakultas Ilmu Sosial Politik Universitas Lampung. Bandar Lampung
Prayitno dan Erman Amti 1994. Dasar-Dasar Bimbingan dan Konseling . Jakarta Dirjen Dikti

Prayitno 1985. Layanan Bimbingan dan Konseling kelompok dasar dan Profil. Jakarta. Halia Indonesia

Prayitno. 1989. Profesionalisme Konseling dan pendidikan Konseling (Jakarta:Depdikbut Dirjen Dikti P2LPTK

Prayitno. 1994. Dasar-dasar Bimbingan dan Konseling , (Jakarta: PT. Rineka Cipta)

Steinberg, L. 1993. Adolecence 3rd - ed. New York: MC Graw-Hill

Shaw, marvin E (1981). Group Dynamics: The Psychology of Small Group Behavior, New York: McGraw-Hill Book Company.

Santrock John.W,2004. Education psychology, 2de Edition. McGraw-Hill Company,Inc. Terjemah Tri Wibowo B.S. Jakarat: Kencana

Sudjana, N. (1989). Dasar - dasar Proses Belajar Mengajar. Bandung: Sinarbaru

Wingkel. 1981. Bimbingan dan penyuluhan disekolah, (Jakarta: PT. Gramedia)

Walgito, Bimo, 2004.Bimbingan dan Konseling disekolah, (Yogyakarta: ANDI OFFSET,)

Wiriaatmadja, R. (2006), Metode Penelitian Tindakan Kelas, Bandung: PT. Remaja Rosdakarya

Zubaedi. 2011. Desain Pendidikan Karakter: Konsepsi dan Aplikasinya dalam Lembaga Pendidikan. Jakarta: Kencana Prenada Media Group.

Wina Sanjaya, 2008. Teori dan Perkembangan anak. Jakarta: Gramedia Citra

http://rafiuddinsyam.blogspot.com/2011/07/makalahpendidikan-karakter-Siswa.html

https://edukasi.kompas.com/read/2018/09/07/23340011/5 -karakter-ini-perlu-ditanamkan-sejak-dini-disekolah?page $=$ all

$\underline{\text { http://temantakita.com/kemerdekaan-belajar/ }}$

http://www.disdik.jabarprov.go.id/news/1807/merdekabelajar-sebagai-bentuk-pemenuhan-aspek-pendidikan

https://kumparan.com/najelaa-shihab/merdeka-belajarkomitmen-pada-tujuan

Wahab, Abdul dan Lestari, Lies Amin. 1999. Menulis Karya Ilmiah. Surabaya: Airlangga University Press.

Winardi, Gunawan. 2002. Panduan Mempersiapkan Tulisan Ilmiah. Bandung: Akatiga. 